\title{
Signaling of Receptor Tyrosine Kinases in the Nucleus
}

\author{
Sally-Anne Stephenson, Inga Mertens-Walker and Adrian Herington \\ Queensland University of Technology, \\ Australia
}

\section{Introduction}

Since the discovery of the first receptor tyrosine kinase (RTK) proteins in the late 1970s and early 1980s, many scientists have explored the functions of these important cell signaling molecules. The finding that these proteins are often deregulated or mutated in diseases such as cancers and diabetes, together with their potential as clinical therapeutic targets, has further highlighted the necessity for understanding the signaling functions of these important proteins. The mechanisms of RTK regulation and function have been recently reviewed by Lemmon \& Schlessinger (2010) but in this review we instead focus on the results of several recent studies that show receptor tyrosine kinases can function from subcellular localisations, including in particular the nucleus, in addition to their classical plasma membrane location. Nuclear localisation of receptor tyrosine kinases has been demonstrated to be important for normal cell function but is also believed to contribute to the pathogenesis of several human diseases.

\section{Classical signaling by receptor tyrosine kinases}

The ability of a cell to receive signals from the outside, and deliver these inside so it can respond appropriately and in co-ordination with other cells, is required for the correct functioning of a multicellular organism as a whole. Cells communicate in two key ways direct physical interaction or by way of communication molecules. These communication molecules, collectively called ligands, include those (eg steroid hormones, vitamins) that can pass directly through the lipid bilayer of the cell and interact with intracellular proteins and those such as protein hormones and peptide growth factors which cannot enter the cell directly. These latter ligands interact with plasma membrane-associated proteins called receptors to activate cascades of interactions between intracellular proteins that can result in a diverse range of responses and ultimately determine cell behaviour (Figure 1).

One large family of membrane receptors, the receptor tyrosine kinases (RTKs), is characterised by their intrinsic protein tyrosine kinase activity, an enzymatic function which catalyses the transfer of the $\gamma$ phosphate of ATP to hydroxyl groups on tyrosine residues on target proteins (Hunter, 1998). Binding of the ligand stabilises dimers of the receptors to allow autophosphorylation via activation of the receptors' intrinsic tyrosine kinase activity that then initiates a network of sequentially acting components such as those of the 
Ras/MAPK (mitogen-activated protein kinase) pathway, or single component systems, such as the STAT pathway. The combination of the activated signal transduction pathways constitute the mechanism by which this intracellular transfer of biochemical information is mediated and can determine the biological responses of cells to growth factors. Members of the RTK family play important roles in the control of most fundamental cellular processes including cell proliferation and differentiation, cell cycle, cell migration, cell metabolism and cell survival.

\section{OUTSIDE CELL}

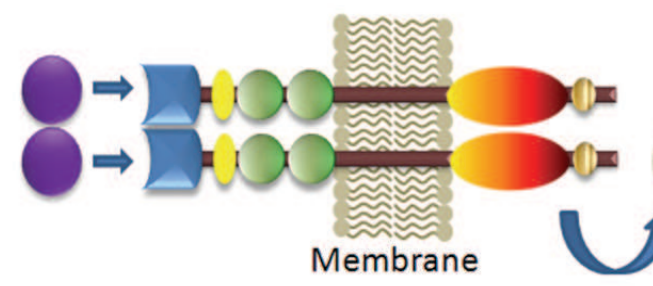

INSIDE CELL

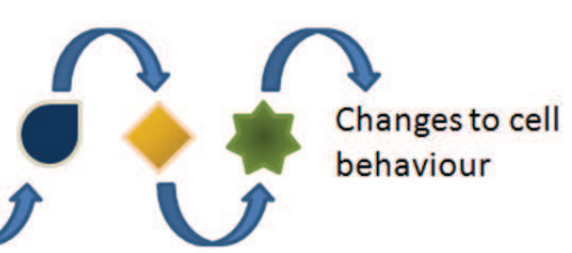

\section{Ligand}

Receptor

\section{Intracellular signaling cascade}

Fig. 1. Classical receptor tyrosine kinase signaling. Ligand binding stablilises dimers of the receptors within the plasma membrane. Autophosphorylation of one intracellular kinase domain by the other activates a signal transduction cascade into the cell so the cell can respond appropriately.

\section{Protein structures of receptor tyrosine kinases}

The general structure of RTK proteins is similar and all members of the RTK family have an intracellular kinase domain through which signaling is mediated by phosphorylation of tyrosine residues. In addition to the kinase domain, all RTKs have an extracellular domain, usually glycosylated, separated from the cytoplasmic part, containing the kinase domain, by a single hydrophobic transmembrane $\alpha$ helix. With the exception of the insulin (IR) and insulin-like growth factor (IGFR) receptor families, which are disulfide linked dimers of two polypeptide chains ( $\alpha$ and $\beta$ ) that form a heterodimer $(\alpha 2 \beta 2)$, RTKs are normally present as monomers in the cell membrane. Ligand binding induces receptor dimerisation resulting in autophosphorylation (the kinase domain of one RTK monomer cross-phosphorylates the other and vice versa). Receptor dimerisation is further stabilised by receptor:receptor interactions and the clustering of many receptors into lipid rich domains on the cell membrane (Pike, 2003). Further division of the 58 human RTKs into 20 different classes is based on similarities in primary structure, and the combinations of further functional domains in both extracellular and intracellular parts of the proteins (Figure 2).

\section{Trafficking of receptor tyrosine kinases}

Ligand activation of receptor tyrosine kinases present on the plasma membrane of cells promotes numerous downstream signal transduction pathways that result in cell responses including proliferation, migration and differentiation. Following ligand activation, virtually all receptor tyrosine kinases are rapidly endocytosed. This would allow the cell to 
discriminate new signals from old ones but it has been suggested that, because trafficking is a complex and highly regulated process, it is likely that endocytosis provides more than just a mechanism for removal of receptor-ligand complexes from the cell surface. Endocytosed receptors can be either recycled back to the membrane after disengagement of the ligand, or targeted for lysosomal degradation. Most receptor tyrosine kinases are internalised via clathrin-coated pits which then shed the clathrin and deliver the internalised receptor-ligand complexes to early endosomes. Bifurcation of receptor trafficking occurs in the early endosomes, allowing either recycling back to the plasma membrane or degradation through lysosomes. In some cases continued signaling from the endosomes has also been demonstrated (Ceresa \& Schmid, 2000; Di Fiore \& De Camilli, 2001; Wang et al., 2004a).

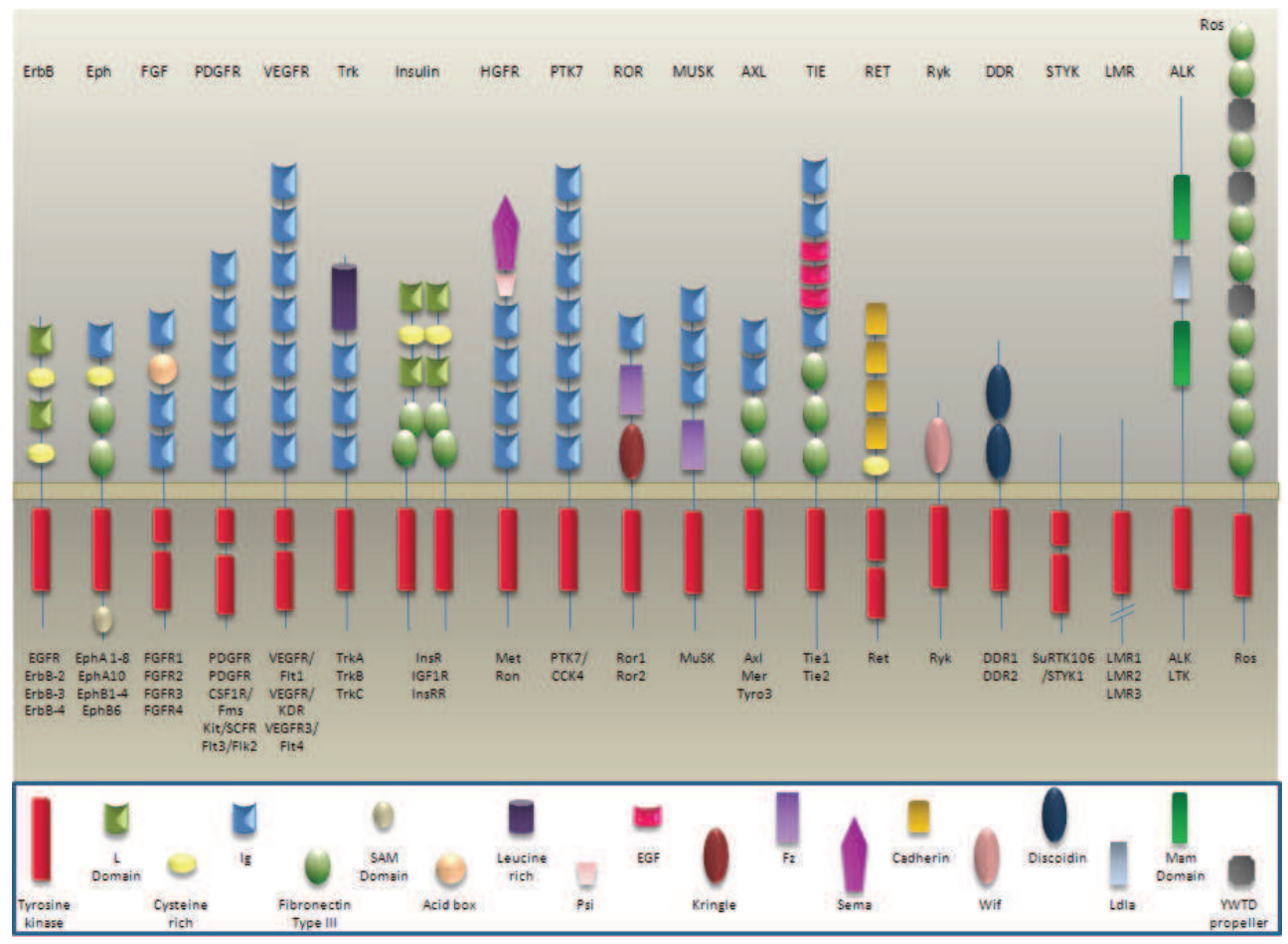

Fig. 2. Domain structures of 58 human receptor tyrosine kinases determines their subclassification into 20 different families. The name of each family is shown above with the members listed below. A key indicates the various motifs common to individuals within that family.

Recent data also suggest that endocytosis controls sub-cellular localisation of activated receptors and their signaling complexes (Beguinot et al., 1984; Sorkin \& Waters, 1993). For example, the prototypical receptor tyrosine kinase, the Epidermal Growth Factor Receptor (EGFR), has been found in caveoli, Golgi, endoplasmic reticulum, lysosome-like structures and nuclear envelopes (Carpentier et al., 1986; Lin et al., 2001). Given the continuity of the endomembrane system, linking endoplasmic reticulum, Golgi membranes, the plasma 
membrane, vesicles of both the endosomal and lysosomal systems and even the nuclear membrane, it is probably not surprising that receptors would be found within the membranes of these structures.

It also appears that endocytosis and trafficking of vesicles is involved in localisation of receptor tyrosine kinases to the nucleus. Nuclear localisation of receptor tyrosine kinases has emerged as a highly significant occurrence in the last decade, with reports indicating that the EGFR (ErbB-1 and -2), FGFR1 and IGF-IR can all translocate to the nucleus as full-length receptors or protein fragments devoid of the extracellular domain. In some cases this has been found to be ligand-dependent, within as early as 2 minutes of ligand stimulation, although there are also cases in which nuclear translocation appears to be ligandindependent. Nuclear localisation of several receptor tyrosine kinases has been identified in cells of normal tissues, including EGFR in the nucleus of regenerating liver cells (Marti and Wells, 2000) and ErbB-4 in the nuclei of secretory epithelium in the lactating breast (Long et al., 2003; Tidcombe et al., 2003). For many receptor tyrosine kinases, also including EGFR and ErbB-4, nuclear localisation has been linked to diseases including cancer, diabetes and inflammation (Citri \& Yarden, 2006; Lo \& Hung, 2006; Massie \& Mills, 2006; Bublil \& Yarden, 2007; Wang \& Hung, 2009; Wang et al., 2010). For example, the nuclear presence of EGFR is associated with high grade breast and ovarian cancers and is associated with the development of resistance to some radio-, chemo- and monoclonal antibody-therapies (Lo et al., 2005a; Xia et al., 2009).

\section{Mechanisms of receptor tyrosine kinase translocation to the nucleus}

It has been hypothesised that in order for a receptor tyrosine kinase to translocate to the nucleus it must somehow 'escape' from the lipid bilayer of the cell surface and/or the trafficking of the endomembrane system. Exactly how this happens is only just being explored experimentally, but Wells \& Marti (2002) have proposed three potential 'escape' mechanisms using EGFR as a model receptor tyrosine kinase. In the first, a mutant EGFR protein, lacking the transmembrane domain, forms a dimer with a wild-type receptor on the cell surface. Binding of EGF causes internalisation of the mutant-wild-type dimer via a clathrin-coated pit into an early endosome. The mutant EGFR is disassociated from the wildtype protein in the endosome and released into the cytosol, and from there it is transported into the nucleus. In the second scenario, full-length wild-type EGFR is trafficked from the plasma membrane to the endoplasmic reticulum, where it interacts with an accessory protein that removes it from the membrane for translocation into the nucleus. In the third, EGFR is targeted by proteases at the plasma membrane and an intracellular fragment translocates to the nucleus again by interaction with nuclear transport proteins. Recently, Liao \& Carpenter (2007) provided support for the second scenario by showing that EGFR in the endosome associates with an accessory protein Sec61 $\beta$, a component of the Sec61 translocon and is then retrotranslocated from the ER to the cytoplasm and from there translocated to the nucleus by nuclear transport proteins.

\section{Nuclear localisation sequences and importins}

Transport of proteins into the nucleus through the nuclear-pore-complex can be facilitated by the dedicated nuclear transport receptors of the $\beta$-karyopherin family which includes the 
importins (Gorlich and Kutay, 1999). Proteins translocated via importins contain nuclear localisation signals (NLS), a short stretch of amino acids that mediates the transport of proteins into the nucleus (Cokol et al., 2000). NLS motifs can be either monopartite, characterised by a cluster of basic residues preceded by a helix-breaking residue, or bipartite, where two clusters of basic residues are separated by 9-12 residues (Cokol et al., 2000). In the classical process of NLS-mediated nuclear translocation, an importin- $\alpha$ adaptor protein binds to a lysine-rich NLS in the cargo protein. An importin- $\beta$ protein then binds to this importin- $\alpha /$ cargo complex through an NLS in the importin- $\alpha$ protein itself and guides the complex through the nuclear pore. Importin- $\beta$ proteins are the key import mediators and can also bind non-classical NLS motifs, of which there are several types, to transport proteins without requiring importin- $\alpha$ interaction. In addition to basic NLSs, several other small epitopes have been identified that, when phosphorylated, can promote nuclear import (Nardozzi et al., 2010). These include the nuclear transport signal (NTS) of ERK1/2, which is a Ser-Pro-Ser (SPS) motif that, upon stimulation, is phosphorylated and functionally active as a binding site for the nuclear transport receptor importin- $\beta 7$ (Chuderland et al., 2008).

\section{Receptor tyrosine kinases reported to translocate to the nucleus}

\subsection{Epidermal Growth Factor Receptor (EGFR)/ErbB family}

The Epidermal Growth Factor Receptor (EGFR) family of receptor tyrosine kinases, also known as ErbB (named after the viral oncogene v-erb-B2) or Human Epidermal growth factor Receptor (HER) receptors, contains four members: EGFR/ErbB-1/HER1, ErbB2/HER2/Neu, ErbB-3/HER3 and ErbB-4/HER4. These receptors are expressed in various tissues of epithelial, mesenchymal and neuronal origin. Activation of ErbB receptors is controlled by the spatial and temporal expression of their 11 different ligands, all encoded by separate genes and all members of the EGF family of growth factors. These include EGF, epigen, transforming growth factor alpha (TGF- $\alpha$ ), and amphiregulin, which bind EGFR; neuregulins (NRGs) 1,2,3,4, which bind ErbB-3 and/or ErbB-4, and betacellulin, heparinbinding EGF-like growth factor, and epiregulin, which bind EGFR and ErbB-4 (Riese \& Stern, 1998). Ligand binding induces receptor dimerisation, and both homodimers and heterodimers with other ErbBs may be formed, and this then leads to the activation of a diverse range of downstream signaling pathways depending on the dimers and crossactivation of other ErbBs on the cell surface (Stern et al., 1986; Riese et al., 1995; Riese \& Stern, 1998; Zaczek et al., 2005). Heterodimerisation is particularly important for signaling through ErbB-2, which lacks a conventional growth factor ligand, and ErbB-3, which has an inactive/impaired kinase domain.

Excessive EGFR, ErbB-2 and ErbB-3 signaling, as a result of receptor over-expression, mutations or autocrine stimulation, is a well known hallmark of a wide variety of solid tumours and leads to both increased cell proliferation and resistance to growth-inhibitory cytokines (Hynes \& Lane, 2005). In contrast, ErbB-4 appears to be associated with growth suppression and improved patient prognosis in breast cancer (Jones, 2008; Muraoka-Cook et al., 2008). In addition, all four members of the ErbB family have a sub-membrane importin alpha-binding basic NLS that allows transport from the cytosol to the nucleus by the importin $\alpha / \beta$ complex. Consequently, ErbB proteins have been detected in the nucleus of both normal cells and cancer cells (Marti et al., 1991; Marti \& Hug, 1995; Marti \& Wells, 2000; Citri \&Yarden, 2006; Lo \& Hung, 2006; Massie \& Mills, 2006; Bublil \& Yarden, 2007; Wang \& 
Hung, 2009; Wang et al., 2010). In multiple cancer types, nuclear accumulation correlates with poor patient survival, tumor grade, and pathologic stage (Lo et al., 2005a; Psyrri et al., 2005; Junttila et al., 2005; Koumakpayi et al., 2006; Lo \& Hung, 2006; Maatta et al., 2006; Hoshino et al., 2007; Xia et al., 2009; Hadzisejdic et al., 2010).

\subsubsection{Epidermal Growth Factor Receptor (EGFR/ErbB-1/HER1)}

Nuclear EGFR, and its ligands EGF and proTGF- $\alpha$, were first observed in hepatocytes during liver regeneration (Raper et al., 1987; Marti et al., 1991; Marti \& Hug, 1995; Marti \& Wells, 2000; Grasl-Kraupp et al., 2002). Translocation of EGFR to the nucleus is also induced by DNA damage caused by irradiation (UV and ionizing) and cisplatin treatment but this appears to be ligand-independent (Dittmann et al., 2005; Xu et al., 2009). Full length EGFR is translocated into the nucleus through interactions with importin $\beta-1$, the nucleoporin protein Nup358 and proteins known to be involved in endocytotic internalisation of these proteins from the plasma membrane. Once in the nucleus, EGFR has three different roles depending on the initial signal, 1) as a direct regulator of gene transcription, 2) regulating cell proliferation and DNA replication via its kinase function, and 3) DNA repair and chemo- and radio-resistance through protein-protein interactions (Lin et al., 2001; Dittmann et al., 2005; Wang et al., 2006; Das et al., 2007; Kim et al., 2007; Wanner et al., 2008; Hsu \& Hung, 2007). As a direct regulator of gene transcription, the C-terminal domain of EGFR directly interacts with the genome through binding and activating AT-rich sequences in the cyclin D1, nitric oxide synthetase (iNOS), Aurora-A and B-myb promoters (Liao and Carpenter, 2007; Lo, 2010). Nuclear EGFR interacts with STAT5 or STAT3 to transactivate the expression of the Aurora-A or iNOS genes respectively (Hung et al., 2008; Lo et al., 2005b). Nuclear EGFR can regulate cell proliferation and DNA replication by direct tyrosine phosphorylation of target proteins including chromatin bound proliferating cell nuclear antigen (PCNA) (Wang et al., 2006). EGFR kinase activity phosphorylates PCNA on tyrosine 211, stabilising the PCNA protein and stimulating DNA replication. In its third role, nuclear EGFR stimulates DNA repair by forming a direct protein-protein interaction with DNAdependent protein kinase (DNA-PK) (Dittmann et al., 2005).

In addition to localisation to the plasma membrane and the nucleus, EGFR has also been found in the Golgi Apparatus, endoplasmic reticulum and the mitochondria (Carpentier et al., 1986; Lin et al., 2001; Boerner et al., 2004). EGFR was first reported in the mitochondria by Boerner et al., (2004) who found that in the presence of EGF, Src mediated the phosphorylation of EGFR residue Y845. EGFR phosphorylated at Y845 was found in the mitochondria and interacted with cytochrome c oxidase subunit II (CoxII) to possibly regulate cell survival. The method by which EGFR is translocated to the mitochondria is unknown, but was not related to endocytotsis of the EGFR protein and did not involve the function of Shc adaptor proteins (Yao et al., 2010). Furthermore, deletion studies showed that a putative mitochondrial-targeting signal between amino acids 646 and 660 was only partially responsible for migration (Boerner et al., 2004).

\subsubsection{ErbB-2/HER2/Neu}

Although ErbB-2 is catalytically active, it cannot bind the heregulin (HRG) ligand directly, but instead dimerises with either HRG-bound ErbB-3 or ErbB-4 to form a complex that is 
capable of signaling through either ErbB-2 or ErbB-4 (ErbB-3 is catalytically inactive/impaired) (Carraway et al., 1994). Upon HRG stimulation, cell-membrane embedded ErbB-2 migrates from the cell surface via early endosomes and is then either targeted to lysosomes for degradation, or recycled back to the surface. By an as yet undefined mechanism, ErbB-2 can also be removed from the lipid bilayer to form a complex with both importin $\beta 1$ and EEA1 (Giri et al., 2005). This complex then moves through the nuclear pore complex into the nucleus. Once in the nucleus, ErbB-2 can form a complex with $\beta$-actin and RNA polymerase-1, enhancing binding of RNA pol 1 to rDNA, and progressing the early and elongation steps of transcription to expedite rRNA synthesis and protein translation ( $\mathrm{Li}$ et al., 2011). The nuclear function of ErbB-2 would appear to be unrelated to its normal signaling role transduced through PI3-K and MEK/ERK because inhibitors to these kinases (LY294002 and U0126, respectively) did not affect the levels of 45S pre-rRNA in these cells. In addition to this role in expediting overall rRNA synthesis and protein translation, nuclear ErbB-2 has also been shown to bind to the promoter of the cyclooxygenase enzyme $(\mathrm{COX}-2)$ and up-regulate its expression. $\mathrm{COX}-2$ catalyzes the conversion of lipids to inflammatory prostaglandin and contributes to increased antiapoptotic, pro-angiogenic, and metastatic potential in cancer cells (Vadlamudi et al., 1999; Howe et al., 2001; Gupta \& DuBois, 2001; Half et al., 2002; Subbaramaiah et al., 2002; Turini \& DuBois, 2002). The promoters of PRPK, MMP16 and DDX10 have also been identified as direct targets of nuclear ErbB-2 (Wang et al., 2004b).

\subsubsection{ErbB-3/HER3}

The kinase domain of ErbB-3 has been described as either catalytically inactive or impaired. Despite this ErbB-3 forms dimers with other ErbB receptors, and can recruit novel proteins to activate diverse signaling pathways (Guy et al., 1994; Zaczek et al., 2005). Intact ErbB-3 was detected in nuclei of prostate cancer cells in metastatic specimens (Koumakpayi et al., 2006; Cheng et al., 2007). Nuclear localisation was then studied in a model of prostate cancer using the MDA-PC $2 \mathrm{~b}$ cells and this demonstrated that both the tumour microenvironment and androgen status influenced nuclear localisation of ErbB-3 in these cells (Cheng et al., 2007). Metastasis of prostate cancer cells to the bone and depletion of androgens from subcutaneous tumours both increased the nuclear translocation of ErbB-3. This also correlated with a decrease in cell proliferation. Once the tumours resumed aggressive growth, ErbB-3 then relocalised from the nucleus to the membrane and cytoplasm of the prostate cancer cells. This suggests that nuclear ErbB-3 may be involved in the progression of prostate cancer in bone after androgen-ablation therapy. ErbB-3 has also been identified in the nucleus, and possibly within the nucleolus, of both normal and malignant human mammary epithelial cells (Offterdinger et al., 2002). The role of nuclear ErbB-3 in these cells has not been determined but yeast two-hybrid approaches have been used to identify several transcription factors that associate with ErbB-3 including p23/p198 (Yoo \& Hamburger, 1999), early growth response-1 (Thaminy et al., 2003) and the zinc finger protein ZNF207 (Thaminy et al., 2003) suggesting a gene regulation function. Finally, alternative transcription initiation of the ErbB-3 gene in Schwann cells leads to the production of a nuclear targeted variant of ErbB-3 that binds to chromatin and regulates the transcriptional activity of the ezrin and HMGB1 genes (Adilakshmi et al., 2011). 


\subsubsection{ErbB-4/HER4}

ErbB-4 has multiple functions during embryogenesis (Gassmann et al., 1995) and expression has recently been shown to be essential during breast development and lactation. In the lactating breast, ErbB-4 localizes to the nuclei of secretory epithelium (Long et al., 2003; Tidcombe et al., 2003). A unique proteolytic cleavage mechanism leads to the nuclear translocation of an intracellular fragment of ErbB-4. Cell membrane expressed ErbB-4 is successively cleaved by TACE/ADAM17, to release the ectodomain, and then $\gamma$-secretase to release an $80 \mathrm{kDa}$ soluble intracellular fragment (s80) ( $\mathrm{Ni}$ et al., 2001). This active kinase fragment binds to YAP (Yes-associated protein) which facilitates its translocation to the nucleus (Komuro et al., 2003). ErbB-4 also has three potential polycationic NLSs in its carboxy-terminal part which may provide an alternative route for nuclear translocation (Williams et al., 2004). The ErbB-4 s80 fragment functions as a nuclear chaperone for the STAT5A, co-translocating this transcription factor and regulating the expression of target genes including $\beta$-casein by binding with STAT5 to the $\beta$-casein promoter (Long et al., 2003; Williams et al., 2004). ErbB-4 also contains a nuclear export signal (NES) recognised by exportin proteins allowing transport of the protein out of the nucleus as well.

\subsection{Fibroblast growth factor receptor family}

The fibroblast growth factor (FGF) family consists of 18 secreted polypeptidic growth factors that bind to four high-affinity receptors (FGFR1-4) and assist in the regulation of cell proliferation, survival, migration and differentiation during development and in adult tissue homeostasis (Wesche et al., 2011). FGFs also bind to low-affinity heparan sulfate proteoglycans (HSPGs) present on most cells, which assist in the formation of the FGF-FGFR complex and protect the ligands from degradation. Overactivity of FGFR signaling is associated with several developmental disorders and cancer (Wesche et al., 2011).

\subsubsection{FGFR1 (Fibroblast growth factor receptor 1)}

Nuclear localisation of full length FGFR1 has been reported in astrocytes, glioma cells, neurons, fibroblasts and retinal cells and has been shown to be important for neuronal differentiation in the central nervous system (Stachowiak et al., 2003a; Stachowiak et al., 2003b). Nuclear accumulation is induced by many different stimuli including activation of acetylcholine receptors, stimulation of angiotensin II receptors, activation of adenylate cyclase or protein kinase C. Biotinylation of cell surface proteins showed that nuclear FGFR1 was unlikely to have been derived from the cell surface (Stachowiak et al., 1997; Peng et al., 2002). Because nuclear FGFR1 is glycosylated the suggestion is that the protein is at least partially processed through the ER-Golgi but that it is not stable in the endomembrane system and is released into the cytosol (Myers et al., 2003). It is also not clear how FGFR1 is then translocated to the nucleus as it lacks a typical NLS. However, several members of the fibroblast growth factor (FGF) family, including FGF-1 and FGF-2, lack signal peptide sequences and are therefore found in trace amounts, if at all, outside of cells. Some of these, for example FGF-2, have nuclear localisation sequences and are highly concentrated in the cell nucleus and it is believed that these FGF ligands act as chaperones for the translocation of receptors like FGFR1 into the nucleus (Myers et al., 2003). Although FGFR1 in the nucleus has been demonstrated to have FGF-regulated kinase activity and is phosphorylated, there 
appears to be limited co-localisation of FGF-2 and FGFR1 in the nucleus (Peng et al., 2002). Nuclear FGFR1 physically interacts with Ribosomal S6 Kinase isoform 1 (RSK1) and regulates its transcriptional activity (Hu et al., 2004). Target genes include FGF-2, c-jun, cyclin D1 and MAP2, genes that are involved in cell growth and differentiation (Reilly \& Maher, 2001). FGFR1 has also been shown to be involved in the activation of the tyrosine hydroxylase promoter that is mediated through a cAMP responsive element (CRE) (Fang et al., 2005).

\subsubsection{FGFR2}

FGFR2 has been identified in the nuclei of quiescent Sertoli cells in the testes (Schmahl et al., 2004). In this study of FGF-9 knock-out mice, FGFR2 nuclear localisation was shown to correlate with male sex determination in the early gonads. The presence of FGFR2 in the nucleus coincides with the expression of the sex-determination gene Sry and the differentiation of progenitor cells in the gonads into Sertoli cells.

\subsubsection{FGFR3}

FGFR3 is a major negative regulator of linear bone growth and gain of function mutations cause the most common forms of dwarfism in humans as these are anti-proliferative (Colvin et al., 1996; Deng et al., 1996). Somatic mutations have been detected in several cancers where, by contrast, they are believed to drive proliferation and inhibit apoptosis (Trudel et al., 2004). Binding of FGF-1 to FGFR3 induces endocytosis via a dynamin/clathrin-mediated process to an endosomal compartment. Here the ectodomain is proteolytically cleaved possibly by an endosomal cathepsin although this has not yet been confirmed. The membrane anchored intracellular fragment is then cleaved in a second event by $\gamma$-secretase to generate a soluble intracellular domain that is released into the cytosol and can translocate to the nucleus. This requirement for endocytosis distinguishes FGFR3 proteolysis from that of most other RTKs.

\subsection{VEGFR (Vascular endothelial growth factor receptor)}

Cellular responses to the ligand vascular endothelial growth factor (VEGF) are activated through two structurally related receptors, VEGFR-1 (Flt-1) and VEGFR-2 (KDR) and are critically important in the regulation of endothelial cell growth and function (Cross et al., 2003). Stimulation of endothelial cells with VEGF induced the translocation of VEGFR-2, eNOS and caveolin-1 into the nucleus (Feng et al., 1999). The consequences of nuclear localisation of these three proteins have yet to be clarified. Non-endothelial expression of VEGFR-2 has also been reported (Stewart et al., 2003). A recent study by Susarla et al., (2011) identified VEGFR-2 expression on normal thyroid follicular cells. The VEGFR-2 expressed by these cells was phosphorylated and, although there was some staining in the cytoplasm, the highest concentration of VEGFR-2 was seen in most nuclei. VEGFR-1 and VEGFR-3 immunoreactivity was also seen predominantly in the nucleus with VEGFR-1 also localised at points of cell to cell contact. The role that VEGF receptors play in the nucleus has not been determined but the intranuclear staining was not co-incidental with chromatin and it is therefore unlikely that VEGFR proteins act as transcription factors. 


\subsection{Insulin receptor}

Insulin is secreted by pancreatic $\beta$-cells in response to an increase in circulating glucose level to trigger tissues to increase glucose uptake and suppress hepatic glucose release. This biological action of insulin is initiated by binding to the insulin receptor InsR (Youngren, 2007). The presence of InsR in the nucleus was first reported in 1987 by Podlecki et al., but more recently this was further characterised by Rodrigues et al., (2008) who demonstrated that the insulin receptor appears in the nucleus of hepatocytes within $2.5 \mathrm{~min}$ of stimulation with insulin. This translocation event was associated with selective hydrolysis of nuclear PIP2 and formation of InsP3-dependent $\mathrm{Ca}^{2+}$ signaling within the nucleus that regulates glucose metabolism, gene expression and cell growth (Poenie et al., 1985; Hardingham et al., 1997; Nathanson et al., 1999; Pusl et al., 2002; Rodrigues et al., 2007). Nelson et al., (2011) have identified two potential gene targets for InsR in the nucleus, the early growth response 1 (egr-1) gene that is involved in the mitogenic response, and the glucokinase $(G c k)$ gene which encodes a key metabolic enzyme.

\subsection{IGF-1R (Insulin-like growth factor 1 receptor)}

The insulin-like growth factor 1 receptor (IGF-1R) plays crucial roles in development and is often over-expressed in cancer. Stimulation with insulin-like growth factor 1 (IGF-I) or 2 (IGF-II) promotes cell proliferation, anti-apoptosis, angiogenesis, differentiation and development. Over-expression of IGF-1R is common in cancer but the mechanisms underlying the role of IGF-1R are not fully understood. Recently, Sehat et al., (2010) showed that IGF-I promotes the modification of IGF-1R by small ubiquitin-like modifier protein-1 (SUMO-1) and this then mediates translocation of IGF-1R to the nucleus. Nuclear import was also enhanced by stimulation with IGF-II but only modestly by insulin, in keeping with the affinity of IGF-1R for these ligands. Full length IGF-1R $\alpha$ and IGF-1R $\beta$ chains which make up the multi-subunit IGF-1R are found in the nucleus (Aleksic et al., 2010). Although it has been reported that IGF-1R binds to chromatin and acts directly as a transcriptional enhancer, direct transcriptional effects of nuclear IGF-1R are yet to be identified.

SUMOylation is initiated by a SUMO activating enzyme, such as SAE1 or SAE2, followed by a transfer of the active SUMO to Ubc9, the only known SUMO-conjugating enzyme, which then catalyses the transfer of SUMO to the target protein (Wilkinson and Henley, 2010). Seventy-five percent of known SUMO targets are modified within the consensus motif $\psi \mathrm{K} x \mathrm{D} / \mathrm{E}$ where $\psi$ is a hydrophic amino acid and $\mathrm{x}$ is any residue ( $\mathrm{Xu}$ et al., 2008). Four SUMO isoforms have been identified in mammalian cells and SUMO-1 is the most widely studied member. Modification by SUMO-1 can result in a variety of functional consequences ranging from transcriptional repression (Garcia-Dominguez \& Reyes, 2009) to DNA repair, mainly through targeting of p53 and BRCA1 (Bartek \& Hodny, 2010), protein stability (Cai \& Robertson, 2010) and cytoplasmic-nuclear shuttling (Salinas et al., 2004; Miranda et al., 2010; Sehat et al., 2010). Currently, IGF-1R is the only receptor tyrosine kinase for which nuclear translocation may be regulated by SUMOylation.

\subsection{Eph receptors}

Eph receptors are the largest group of transmembrane receptor tyrosine kinases with 14 human members divided into 2 subclasses, EphA (EphA1-EphA8, EphA10) and EphB (EphB1-EphB4, EphB6) (Pitulescu \& Adams, 2010). Eph receptors are activated by their 
ligands the ephrins, proteins that are anchored to the plasma membrane of a neighbouring cell by either a glycosylphosphatidylinositol (GPI) anchor (type A) or a transmembrane amino acid sequence (type B). Eph-ephrin signaling plays important roles in neuronal and vascular development and many are over-expressed in various cancers (Flanagan \& Vanderhaeghen, 1998; Adams \& Klein, 2000; Stephenson et al., 2001; Lee et al., 2005; Pasquale, 2005; Chen et al., 2008).

To date only a single member of the Eph family, EphA4, has been reported in the nucleus (Kuroda et al., 2008). EphA4 is critically involved in development of neural tissue and more recently has been identified in hypertrophic chondrocytes and osteoblasts in the growth plate of developing mouse long bones (Kuroda et al., 2008). In the human osteoblastic cell line SaOS-2, EphA4 was found on the plasma membrane as expected, but also in the cytoplasm and in the nucleus. EphA4 accumulated in particular areas in the nucleus, but these were distinct from the nucleolus. It is not clear whether the EphA4 in the nucleus is full-length or a processed intracellular fragment and the role of EphA4 in the osteoblast nucleus has not been explored to date.

\subsection{Ryk (Related to Receptor Tyrosine Kinase)}

Ryk is a Wnt receptor that plays an important role in neurogenesis, neurite outgrowth, and axon guidance. Although a catalytically inactive receptor tyrosine kinase, Ryk is believed to signal via heterodimerisation with other receptor tyrosine kinases and has been shown to bind two members of the Eph receptor family, EphB2 and EphB3 (Halford et al., 2000). In neural progenitor cells, upon binding of Wnt3a, Ryk is cleaved at an intracellular site and the C-terminal cleavage product, Ryk ICD, translocates to the nucleus. Recently it was shown that Cdc37, a subunit of the molecular chaperone Hsp90 complex, binds to the Ryk ICD, promoting stabilization of the ICD fragment and providing the mechanism for nuclear translocation. Once in the nucleus, Ryk ICD regulates the expression of the key cell-fate determinants Dlx2 (stimulated) and Olig2 (inhibited) to promote GABAergic neuronal differentiation and inhibition of oligodendrocyte differentiation (Zhong et al., 2011).

\subsection{Ror (RTK-like orphan receptor)}

Ror1 and Ror2 receptor tyrosine kinases are involved in the development of mammalian central neurons (Paganioni \& Ferreira, 2003; Paganioni \& Ferreira, 2005). Although the ligand of Ror2 has been identified as Wnt-5A (Liu et al., 2008), Ror1 remains an orphan receptor protein tyrosine kinase without an identified interacting ligand. Tseng et al., (2010) used an in silico approach to predict receptor tyrosine kinases with likely nuclear localisation. Ror1 and Ror2 were identified in a panel that included receptors with known nuclear localisation including ErbB proteins, FGFR proteins and VEGFR proteins. The juxtamembrane domain of Ror1, responsible for nuclear localisation of this protein, was identified using deletion reporter constructs and the small GTPase Ran was identified as playing a key role in the nuclear transport. The function of Ror1 in the nucleus remains to be determined.

\subsection{Trk (Tropomyocin Receptor Kinase)}

Neurotrophins are a family of protein nerve growth factors that are critical for the development and functioning of the nervous system, regulating a wide range of biological 
processes. The receptors for neurotrophins are the Trk receptors - TrkA (or NTRK1), TrkB (or NTRK2), and TrkC (or NTRK3). Binding of neurotrophins to Trk receptors promotes both neuronal cell survival and death by activating signal transduction cascades including Ras/MAPK (mitogen-activated protein kinase) pathway and the PI3K (phosphatidylinositol 3-kinase) pathway. TrkA accumulates in the nucleus and on the mitotic apparatus of the human glioma cell line U251 after binding the neurotrophin ligand, nerve growth factor (NGF) (Gong et al., 2007). Translocation of phosphorylated TrkA is via carrier vesicles which sort and concentrate the receptors. These vesicles then interact with the nuclear envelope but how the TrkA protein is then removed from the membrane to move into the nucleoplasm is unclear. Once in the nucleus of the U251 glioma cells, TrkA co-localises with $\alpha$-tubulin at the mitotic spindle. Interestingly, it has been shown that NGF co-localises with $\gamma$-tubulin at the centrosomes or spindle poles. Zhang et al., (2005) suggest that NGF concentrated to the centrosome can recruit its receptor TrkA from the nucleoplasm, activate the tyrosine kinase activity of the receptor to phosphorylate the tubulin and promote the mitotic spindle assembly that modulates the mitosis of human glioma cells.

\subsection{HGFR (Hepatocyte growth factor receptor)}

The HGFR family includes three members, MET, RON and SEA, produced mainly by cells of epithelial origin, which bind hepatocyte and hepatocyte-like growth factors secreted by mesenchymal cells, to regulate cell growth, cell motility, and morphogenesis (Comoglio \& Boccaccio, 1996). Members of the HGFR family are described as oncoproteins because overexpression and/or abnormal activity correlates with the poor prognosis of many cancers (Accornero et al., 2010).

\subsubsection{MET}

Hepatocyte growth factor (HGF) secreted by stromal cells is a mitogenic factor and binds to MET on hepatocytes to activate pathways involved in cell proliferation, differentiation, and related activities that aid tissue regeneration in the liver. Other cell targets of HGF include epithelium, endothelium, myoblasts, spinal motor neurons, and hematopoietic cells. MET over-expression and hyper-activation are reported to correlate with metastatic ability of the tumor cells of several different tissue origins. Gomes et al., (2008) used the SkHep1 liver cell line to show that stimulation of cells with HGF caused the rapid translocation of phosphorylated MET from the plasma membrane to the nucleus, with peak levels detected after only 4 min of HGF exposure. Translocation of MET to the nucleus was mediated by binding of Gab1, an adaptor protein that contains a NLS for importin-driven translocation. In the nucleus, MET was shown to initiate nuclear $\mathrm{Ca}^{2+}$ signaling that stimulates cell proliferation (Rodrigues et al., 2007).

\subsubsection{RON (Recepteur d'origine nantais)}

RON is a receptor tyrosine kinase whose expression is highly restricted to cells of epithelial origin (Wang et al., 2010). Its ligand is the HGF-like macrophage stimulating protein (MSP) which stabilises two monomers of RON as a homodimer on the cell membrane. RON has been shown to be aberrantly expressed or mutated in many cancers 
including those from the bladder, breast, colon, lung, ovary, pancreas and prostate, particularly in aggressive tumours associated with poor patient survival (reviewed in Wang et al., 2010). Activated RON can promote c-Src activities that mediate cell-cycle progression, angiogenesis and survival of tumor cells (Danilkovitch-Miagkov et al., 2000; Feres et al., 2009). In bladder cancer cells, under conditions of serum starvation, RON has been shown to migrate from the cell membrane to the nucleus in a complex with EGFR with passage through the nuclear pore complex mediated by importins. In the nucleus, RON and EGFR co-operate in the transcriptional regulation of at least 134 different target genes known to participate in three stress-responsive networks: p53 (genes included RBBP6, RB1, TP53BP2 and JUN), stress-activated protein kinase/c-jun N-terminal kinase (JUN, MAPK8IP3, NFATC1 and TRADD) and phosphatidylinositol 3-kinase/Akt (GHR, $P P P 2 R 3 B$ and PRKCZ) (Liu et al., 2010). Nuclear translocation of RON was therefore suggested to be a response to physiological stress. Furthermore, because MSP stimulation, homodimerisation and phosphorylation were not required for nuclear translocation, this is a ligand-independent response in these cells. A consensus sequence for binding nuclear RON was identified as GCA(G)GGGGCAGCG in genes that were both confirmed upregulated (FLJ46072, JUN, MLXIPL, NARG1 and SSTR1) and down-regulated (RBBP6 and POLRMT) after serum starvation.

\section{Conclusion}

Although early reports of the presence of receptor tyrosine kinases in the nucleus of cells was met with scepticism, a significant collection of data now supports a role for many of these proteins in the nucleus of both normal and dysplastic cells. To date, 18 of the 58 human receptor tyrosine kinases have been found within nuclei and it is likely that more will be found. In general, the result of nuclear translocation of receptors is alterations to gene expression, but the full consequences of the presence of these proteins in the nucleus have yet to be determined. Only through further exploration can the complexity that nuclear localisation provides to receptor tyrosine kinase functions be determined.

\section{References}

Accornero, P, Pavone, LM, \& Baratta, M. (2010) The scatter factor signaling pathways as therapeutic associated target in cancer treatment. Current Medicinal Chemistry, Vol. 17, No.25 (September 2010), pp. 2699-712, ISSN 0929-9673

Adams, RH, \& Klein, R. (2000) Eph receptors and ephrin ligands, essential mediators of vascular development. Trends in Cardiovascular Medicine, Vol. 10, No. 5, (July 2000), pp. 183-188, ISSN 1050-1738

Adilakshmi, T, Ness-Myers, J, Madrid-Aliste, C, Fiser, Andras, \& Tapinos, N. (2011) A nuclear variant of ErbB3 receptor tyrosine kinase regulates ezrin distribution and schwann cell myelination. The Journal of Neuroscience, Vol.31, No. 13 (March 2011), pp. 5106-5119, ISSN 0270-6474

Aleksic, T, Chitnis, MM, Perestenko, OV, Gao, S, Thomas, PH, Turner, GD, Protheroe, AS, Howarth, M, Macaulay, VM. (2010) Type 1 insulin-like growth factor receptor 
translocates to the nucleus of human tumor cells. Cancer Research, Vol. 70, No. 16, (August 2010), pp. 6412-6419, ISSN 0008-5472

Bartek, J, \& Hodny, Z. (2010) SUMO boosts the DNA damage response barrier against cancer. Cancer Cell, Vol 17, No. 1, (January 2010), pp. 9-11, ISSN 1535-6108

Beguinot, L, Lyall, RM, Willingham, MC, \& Pastan, I. (1984) Down-regulation of the epidermal growth factor receptor in $\mathrm{KB}$ cells is due to receptor internalization and subsequent degradation in lysosomes. Proceedings of the National Academy of Sciences of the USA, Vol. 81, No. 8, (April 1984), pp. 2384-2388, ISSN 1091-6490

Boerner, JL, Demory, ML, Silva, C, \& Parsons, SJ. (2004) Phosphorylation of Y845 on the epidermal growth factor receptor mediates binding to the mitochondrial protein cytochrome c oxidase subunit II. Molecular and Cellular Biology, Vol. 24, No. 16, (August 2004), pp. 7059-7071, ISSN 0270-7306

Bublil, EM, \& Yarden, Y. (2007) The EGF receptor family: spearheading a merger of signaling and therapeutics. Current Opinion in Cell Biology, Vol. 19, No. 2, (April 2007), pp. 124-134, ISSN 0955-0674

Cai, Q, \& Robertson, ES. (2010) Ubiquitin/SUMO modification regulates VHL protein stability and nucleocytoplasmic localization. PLoS One, Vol. 5, No. 9, (September 2010), pii. e12636, ISSN 1932-6203

Carpentier, JL, Rees, AR, Gregoriou, M, Kris, R, Schlessinger, J \& Orci, L. (1986) Subcellular distribution of the external and internal domains of the EGF receptor in A-431 cells. Experimental Cell Research, Vol. 166, No. 2, (October 1986), pp. 312-326, ISSN 00144827

Carraway, KL 3rd, Sliwkowski, MX, Akita, R, Platko, JV, Guy, PM, Nuijens, A, Diamonti, AJ, Vandlen, RL, Cantley, LC, \& Cerione, RA. (1994) The erbB3 gene product is a receptor for heregulin. Journal of Biological Chemistry, Vol. 269, No. 19, (May 1994), pp. 14303-14306, ISSN 0021-9258

Ceresa, BP, \& Schmid, SL. (2000) Regulation of signal transduction by endocytosis. Current Opinion in Cell Biology, Vol. 12, No. 2, (April 2000), pp. 204 -210, ISSN 0955-0674

Chen, J, Zhuang, G, Frieden, L, \& Debinski, W. (2008) Eph receptors and Ephrins in cancer: common themes and controversies. Cancer Research, Vol. 68, No. 24, (December 2008), pp.10031-10033, ISSN 1538-7445

Cheng, CJ, Ye, XC, Vakar-Lopez, F, Kim, J, Tu, SM, Chen, DT, Navone, NM, Yu-Lee, LY, Lin, $\mathrm{SH}, \& \mathrm{Hu}, \mathrm{MC}$. (2007) Bone microenvironment and androgen status modulate subcellular localization of ErbB3 in prostate cancer cells. Molecular Cancer Research, Vol. 5, No. 7, (July 2007), pp. 675-684, ISSN 1541-7786

Chuderland, D, Konson, A, \& Seger, R. (2008) Identification and characterization of a general nuclear translocation signal in signaling proteins. Molecular Cell, Vol. 31, No. 6 (September 2008), pp. 850-861, ISSN 10197-2765

Citri, A \& Yarden, Y. (2006) EGF-ERBB signalling: towards the systems level. Nature Reviews Molecular Cell Biology, Vol. 7, No. 7, (July 2006), pp. 505-516, ISSN 1471-0072

Cokol, M, Nair, R, \& Rost, B. (2000) Finding nuclear localization signals. EMBO Reports, Vol. 1, No. 5 (November 2000), pp. 411-415, ISSN 1469-3178 
Colvin, JS, Bohne, BA, Harding, GW, McEwen, DG, \& Ornitz, DM. (1996) Skeletal overgrowth and deafness in mice lacking fibroblast growth factor receptor 3. Nature Genetics, Vol. 12, No. 4, (April 1996), pp. 390-397, ISSN 1061-4036

Comoglio, PM, \& Boccaccio, C. (1996) The HGF receptor family: unconventional signal transducers for invasive cell growth. Genes to Cells, Vol. 1, No. 4, (April 1996), pp. 347-354, ISSN 1365-2443

Cross, MJ, Dixelius, J, Matsumoto, T, \& Claesson-Welsh, L. (2003) VEGF receptor signal transduction. Trends in Biochemical Sciences, Vol. 23, No. 9, (September 2003), pp. 488 - 494. ISSN 0968-0004

Danilkovitch-Miagkova,A, Angeloni, D, Skeel, A, Donley, S, Lerman, M, \& Leonard, EJ. (2000) Integrin-mediated RON growth factor receptor phosphorylation requires tyrosine kinase activity of both the receptor and c-Src. Journal of Biological Chemistry, Vol. 275, No. 20, (May 2000), pp. 14783-15147, ISSN 0021-9258

Das, AK, Chen, BP, Story, MD, Sato, M, Minna, JD, Chen, DJ, Nirodi, CS. (2007) Somatic mutations in the tyrosine kinase domain of epidermal growth factor receptor (EGFR) abrogate EGFR-mediated radioprotection in non-small cell lung carcinoma. Cancer Research, Vol. 67, No. 11, (June 2007), pp. 5267-5274, ISSN 1538-7445

Deng, C, Wynshaw-Boris, A, Zhou, F, Kuo, A, \& Leder, P. (1996) Fibroblast growth factor receptor 3 is a negative regulator of bone growth. Cell, Vol. 84, No. 6, (March 1996), pp. 911-921, ISSN 0092-8674

Dittmann, K, Mayer, C, Fehrenbacher, B, Schaller, M, Raju, U, Milas, L, Chen,DJ, Kehlbach, R, \& Rodemann, HP. (2005) Radiation-induced epidermal growth factor receptor nuclear import is linked to activation of DNA-dependent protein kinase. Journal of Biological Chemistry, Vol. 280, No. 35, (September 2005), pp. 31182-31189, ISSN 00219258

Di Fiore, PP, \& De Camilli, P. (2001) Endocytosis and signalling: An inseparable partnership. Cell, Vol. 106, No. 1, (July 2001), pp. 1- 4, ISSN 0092-8674

Fang, X, Stachowiak, EK, Dunham-Ems, SM, Klejbor, I, Stachowiak, MK (2005) Control of CREB-binding protein signaling by nuclear fibroblast growth factor receptor-1: a novel mechanism of gene regulation. Journal of Biological Chemistry, Vol. 280, No. 31, (August 2005), pp. 28451-28462, ISSN 0092-8674

Feng, Y, Venema, VJ, Venema, RC, Tsai, N, \& Caldwell, RB. (1999) VEGF induces nuclear translocation of Flk-1/KDR, endothelial nitric oxide synthase, and caveolin-1 in vascular endothelial cells. Biochemical and Biophysical Research Communications, Vol. 256, No. 1, (March 1999), pp. 192-197, ISSN 0006-291X

Feres, KJ, Ischenko, I, \& Hayman, MJ. (2009) The RON receptor tyrosine kinase promotes MSP-independent cell spreading and survival in breast epithelial cells. Oncogene, Vol. 28, No. 2, (January 2009), pp. 279-288, ISSN 0950-9232

Flanagan, JG, \& Vanderhaeghen, P. (1998) The ephrins and Eph receptors in neural development. Annual Review of Neuroscience, Vol. 21, (1998), pp. 309-345, ISSN 15454126

Garcia-Dominguez, M, \& Reyes, JC. (2009) SUMO association with repressor complexes, emerging routes for transcriptional control. Biochimica et Biophysica Acta, Vol. 1789, No. 6-8, (June-August 2009), pp. 451-459, ISSN 0006-3002 
Gassmann, M, Casagranda, F, Orioli, D, Simon, H, Lai, C, Klein, R, Lemke, G. (1995) Aberrant neural and cardiac development in mice lacking the ErbB4 neuregulin receptor. Nature, Vol. 378. No. 6555, (November 1995), pp. 390-394, ISSN 0028-0836

Giri, DK, Ali-Seyed, M, Li, LY, Lee, DF, Ling, P, Bartholomeusz, G, Wang, SC, \& Hung, MC. (2005) Endosomal transport of ErbB-2:mechanism for nuclear entry of the cell surface receptor. Molecular and Cellular Biology, Vol. 25, No. 24, (December 2005), pp. 11005-11018, ISSN 1471-0072

Gomes, DA, Rodrigues, MA, Leite, MF, Gomez, MV, Varnai, P, Balla, T, Bennett, AM, \& Nathanson, MH. (2008) c-Met must translocate to the nucleus to initiate calcium signals. Journal of Biological Chemistry, Vol. 283, No. 7, (February2008), pp. 43444351.

Gong, A, Zhang, Z, Xiao, D, Yang, Y, Wang, Y, \& Chen Y. (2007) Localization of phosphorylated TrkA in carrier vesicles involved in its nuclear translocation in U251 cell line. Science in China. Series C, Life Science. Vol. 50, No. 2, (April 2007), pp. 141-146. ISSN 1674-7305

Gorlich, D, \& Kutay, U. (1999) Transport between the cell nucleus and the cytoplasm. Annual Review Cell and Developmental Biology, Vol.15, (1999), pp. 607-660, ISSN 10810706

Grasl-Kraupp, B, Schausberger, E, Hufnagl, K, Gerner, C, Low-Baselli, A, Rossmanith, W, Parzefall, W, \& Schulte-Hermann, R. (2002) A novel mechanism for mitogenic signaling via pro-transforming growth factor alpha within hepatocyte nuclei. Hepatology Vol. 3, No. 6, (June 2002), pp. 1372-1380, ISSN 1527-3350

Gupta, RA, \& DuBois, RN. (2001) Colorectal cancer prevention and treatment by inhibition of cyclooxygenase-2. Nature Reviews Cancer, Vol. 1, No. 1, (October 2001), pp. 11-21, ISSN 1474-175X

Guy, PM, Platko, JV, Cantley, LC, Cerione, RA, \& Carraway, KL III (1994). Insect cellexpressed p180erbB3 possesses an impaired tyrosine kinase activity. Proceedings of the National Academy of Sciences of the USA, Vol. 91, No. 17, (August 1994), pp. 81328136. ISSN 1091-6490

Hadzisejdic, I, Mustac, E, Jonjic, N, Petkovic, M, \& Grahovac, B. (2010) Nuclear EGFR in ductal invasive breast cancer: correlation with cyclin-D1 and prognosis. Modern Pathology, Vol. 23, No. 2, (March 2010), pp. 392-403, ISSN 0893-3952

Half, E, Tang, X, Gwyn, K, Sahin, A, Wathen, K, \& Sinicrope, FA. (2002) Cyclooxygenase-2 expression in human breast cancers and adjacent ductal carcinoma in situ. Cancer Research, Vol. 62, No. 6, (March 2002), pp. 1676-1681, ISSN 1538-7445

Halford, MM, Armes, J, Buchert, M, Meskenaite, V, Grail, D, Hibbs, ML, Wilks, AF, Farlie, PG, Newgreen, DF, Hovens, CM, \& Stacker, SA (2000) Ryk-deficient mice exhibit craniofacial defects associated with perturbed Eph receptor crosstalk. Nature Genetics, Vol. 25, No. 4, (August 2000), pp. 414-418, ISSN 1061-4036

Hardingham, GE, Chawla, S, Johnson, CM, \& Bading, H. (1997) Distinct functions of nuclear and cytoplasmic calcium in the control of gene expression. Nature, Vol. 385, No. 6613, (January 1997), pp. 260-265, ISSN 0028-0836

Hoshino, M, Fukui, H, Ono, Y, Sekikawa, A, Ichikawa, K, Tomita, S, Imai, Y, Imura, J, Hiraishi, H, Fujimori, T. (2007) Nuclear expression of phosphorylated EGFR is 
associated with poor prognosis of patients with esophageal squamous cell carcinoma. Pathobiology, Vol. 74, No. 1, (January 2007), pp. 15-21, ISSN 1015-2008

Howe, LR, Subbaramaiah, K, Brown, AM, \& Dannenberg, AJ. (2001) Cyclooxygenase-2: a target for the prevention and treatment of breast cancer. Endocrine Related Cancer, Vol. 8, No. 2, (June 2001), pp. 97-114, ISSN 1351-0088

Hsu, SC, \& Hung, MC (2007) Characterization of a novel tripartite nuclear localization sequence in the EGFR family. Journal of Biological Chemistry, Vol. 282, No. 14, (May 2007), pp. 10432-10440, ISSN 0021-9258

Hu, Y, Fang, X, Dunham, SM, Prada, C, Stachowiak, EK, \& Stachowiak, MK (2004) 90-kDa ribosomal S6 kinase is a direct target for the nuclear fibroblast growth factor receptor 1 (FGFR1): role in FGFR1 signaling. Journal of Biological Chemistry, Vol. 279, No. 28, (July 2004), pp. 29325-29335, ISSN 0021-9258

Hung, LY, Tseng, JT, Lee, YC, Xia, W, Wang, YN, Wu, ML, Chuang, YH, Lai, CH, Chang, WC. (2008) Nuclear epidermal growth factor receptor (EGFR) interacts with signal transducer and activator of transcription 5 (STAT5) in activating Aurora-A gene expression. Nucleic Acids Research, Vol. 36, Np. 13, (August 2008), pp. 4337-4351, ISSN 1362-4962

Hunter T. (1998) The Croonian lecture, 1997. The phosphorylation of proteins on tyrosine: its role in cell growth and disease. Philosophical Transactions of the Royal Society London. Series B, Biological Sciences, Vol. 353, No. 1368, (April 1998), pp. 583-605, ISSN 14712970

Hynes, NE \& Lane, HA. (2005) ERBB receptors and cancer: the complexity of targeted inhibitors. Nature Reviews Cancer, Vol. 5, No. 5 (May 2005), pp. 341-354, ISSN 1474$175 \mathrm{X}$

Jones, FE. (2008) HER4 intracellular domain (4ICD) activity in the developing mammary gland and breast cancer. Journal of Mammary Gland Biology and Neoplasia, Vol. 13, No. 2, (June 2008), pp. 247-258, ISSN 1573-7039

Junttila, TT, Sundvall, M, Lundin, M, Lundin, J, Tanner, M, Harkonen, P, Joensuu H, Isola, J, Elenius, K. (2005) Cleavable ErbB4 isoform in estrogen receptor-regulated growth of breast cancer cells. Cancer Research, Vol. 65, No. 4, (February 2005), pp. 13841393, ISSN 1538-7445

Kim, J, Jahng, WJ, Di Vizio, D, Lee, JS, Jhaveri, R, Rubin, MA, Shisheva, A, \& Freeman, MR. (2007) The phosphoinositide kinase PIKfyve mediates epidermal growth factor receptor trafficking to the nucleus. Cancer Research, Vol. 67, No. 19, (October 2007), pp. 9229-9237, ISSN 1538-7445

Komuro, A, Nagai, M, Navin, NE, \& Sudol, M. (2003) WW domain-containing protein YAP associates with ErbB-4 and acts as a co-transcriptional activator for the carboxylterminal fragment of ErbB-4 that translocates to the nucleus. Journal of Biological Chemistry, Vol. 278, No. 35, (August 2003), pp. 33334-33341, ISSN 0021-9258

Koumakpayi, IH, Diallo, JS, Le Page, C, Lessard, L, Gleave, M, Bégin, LR, Mes-Masson, AM, Saad, F. (2006) Expression and nuclear localization of ErbB3 in prostate cancer. Clinical Cancer Research, Vol. 12, No. 9, (May 2006), pp. 2730-2737, ISSN 1557-3265

Kuroda, C, Kubota, S, Kawata, K, Aoyama, E, Sumiyoshi, K, Oka, M, Inoue, M, Minagi, S, \& Takigawa, M. (2008) Distribution, gene expression, and functional role of EPHA4 
during ossification. Biochemical and Biophysical Research Communications, Vol. 374, No. 1, (September 2008), pp. 22-27, ISSN 0006-291X

Lee, YC, Perren JR, Douglas, EL, Raynor, MP, Bartley, MA, Bardy, PG, \& Stephenson, SA. (2005) Investigation of the expression of the EphB4 receptor tyrosine kinase in prostate carcinoma. BMC Cancer, Vol 5, (September 2005), pp. 119, ISSN 1471-2407

Lemmon, MA \& Schlessinger, J. (2010) Cell signaling by receptor tyrosine kinases. Cell, Vol. 141, No. 7 (June 2010), pp. 1117 - 1134, ISSN 0092-8674

Li, LY, Chen, H, Hsieh, YH, Wang, YN, Chu, HJ, Chen, YH, Chen, HY, Chien, PJ, Ma, HT, Tsai, HC, Lai, CC, Sher, YP, Lien, HC, Tsai, CH, \& Hung, MC. (2011) Nuclear ErbB2 enhances translation and cell growth by activating transcription of ribosomal RNA genes. Cancer Research, Vol. 71, No. 12, (June 2011), pp. 4269-4279, ISSN 0008-5472

Liao, HJ, Carpenter, G. (2007) Role of the Sec61 translocon in EGF receptor trafficking to the nucleus and gene expression. Molecular Biology of the Cell, Vol. 18, No. 3, (March 2007), pp. 1064-1072, ISSN 1059-1524

Lin, SY, Makino, K, Xia, W, Matin, A, Wen, Y, Kwong, KY, Bourguignon, L, \& Hung, MC. (2001) Nuclear localization of EGF receptor and its potential new role as a transcription factor. Nature Cell Biology, Vol. 3, No. 9, (September 2001), pp. 802808, ISSN 1465-7392

Liu, HS, Hsu, PY, Lai, MD, Chang, HY, Ho, CL, Cheng, HL, Chen, HT, Lin, YJ, Wu, TJ, Tzai, TS, \& Chow, NH. (2010) An unusual function of RON receptor tyrosine kinase as a transcriptional regulator in cooperation with EGFR in human cancer cells. Carcinogenesis, Vol. 31, No. 8, (August 2010), pp. 1456-1464, ISSN 0143-3334

Liu, Y, Rubin, B, Bodine, PV, \& Billiard, J. (2008) Wnt5a induces homodimerization and activation of Ror2 receptor tyrosine kinase. Journal of Cellular Biochemistry, Vol. 105, No. 2, (October 2008), pp. 497-502, ISSN 0730-2312

Lo, HW. (2010) Nuclear mode of the EGFR signaling network: biology, prognostic value, and therapeutic implications. Discovery Medicine, Vol. 10, No. 50, (July 2010), pp. 4451, ISSN 1539-6509

Lo, HW, Xia, W, Wei, Y, Ali-Seyed, M, Huang, SF, \& Hung, MC. (2005a) Novel prognostic value of nuclear epidermal growth factor receptor in breast cancer. Cancer Research, Vol. 65, No. 1, (January 2005), pp. 338-348, ISSN 1538-7445

Lo, HW, Hsu, SC, Ali-Seyed, M, Gunduz, M, Xia, W, Wei, Y, Bartholomeusz, G, Shih, JY, \& Hung, MC. (2005b) Nuclear interaction of EGFR and STAT3 in the activation of the iNOS/NO pathway. Cancer Cell, Vol. 7, No. 6, (June 2005), pp. 575-589, ISSN 15356108

Lo, HW, \& Hung, MC. (2006) Nuclear EGFR signalling network in cancers: linking EGFR pathway to cell cycle progression, nitric oxide pathway and patient survival. British Journal of Cancer, Vol. 94, No. 2, (January 2006), pp. 184-188, ISSN 0007-0920

Long, W, Wagner, K-U, Lloyd, KCK, Binart, N, Shillingford, JM, Hennighausen, L, \& Jones, FE. (2003) Impaired differentiation and lactational failure in ErbB4-deficient mammary glands identify ERBB4 as an obligate mediator of Stat5. Development, Vol. 130, No. 21, (November 2003), pp. 5257-5268, ISSN 1011-6370

Maatta, JA, Sundvall, M, Junttila,TT, Peri, L, Laine, VJ, Isola, J, Egeblad, M, \& Elenius, K. (2006) Proteolytic cleavage and phosphorylation of a tumor-associated ErbB4 
isoform promote ligand-independent survival and cancer cell growth. Molecular Biology of the Cell, Vol. 17, No. 1, (January 2006), pp. 67-79, ISSN 1059-1524

Marti, U, Burwen, SJ, Well,s A, Barker ME, Huling S, Feren AM, Jones, AL (1991) Localization of epidermal growth factor receptor in hepatocyte nuclei. Hepatology, Vol.13, No. 1, (January 1991), pp. 15-20, ISSN 1527-3350

Marti, U, \& Hug, M. (1995) Acinar and cellular distribution and mRNA expression of the epidermal growth factor receptor are changed during liver regeneration. Journal of Hepatology, Vol. 23, No. 3, (September 1995), pp. 318-327 ISSN 0168-8278

Marti, U, \& Wells, A. (2000) The nuclear accumulation of a variant epidermal growth factor receptor (EGFR) lacking the transmembrane domain requires coexpression of a full-length EGFR. Molecular Cell Biology Research Communications, Vol. 3, No. 1 (January 2000), pp. 8-14, ISSN 1522-4724

Massie, C \& Mills, IG. (2006) The developing role of receptors and adaptors. Nature Reviews Cancer, Vol. 6, No. 5, (May 2006), pp. 403-409, ISSN 1474-175X

Miranda, KJ, Loeser, RF, \& Yammani, RR. (2010) Sumoylation and nuclear translocation of S100A4 regulate IL-1beta-mediated production of matrix metalloproteinase-13. Journal of Biological Chemistry, Vol. 285, No. 41, (October 2010), pp. 31517-31524.

Muraoka-Cook, RS, Feng, SM, Strunk, KE, Earp 3rd HS. (2008) ErbB4/HER4: role in mammary gland development, differentiation and growth inhibition. Journal of Mammary Gland Biology and Neoplasia, Vol. 13, No. 2, (June 2008), pp. 235-246, ISSN 1083-3021

Myers, JM, Martins, GG, Ostrowski, J, \& Stachowiak, MK. (2003) Nuclear trafficking of FGFR1: a role for the transmembrane domain. Journal of Cellular Biochemistry, Vol. 88, No. 6, (April 2003), pp. 1273-1291, ISSN 0730-2312

Nardozzi, JD, Lott, K, \& Cingolani, G. (2010) Phosphorylation meets nuclear import: a review. Cell Communication and Signaling. Vol. 23, No. 8, (December 2010), pp. 32, ISSN 1478-811X

Nathanson, MH, Rios-Velez, L, Burgstahler, AD, \& Mennone, A. (1999) Communication via gap junctions modulates bile secretion in the isolated perfused rat liver. Gastroenterology, Vol. 116, No. 5, (May 1999), pp. 1176-1183, ISSN 0016-5085

Nelson, JD, LeBoeuf, RC \& Bomsztyk, K. (2011) Direct recruitment of insulin receptor and ERK signaling cascade to insulin-inducible gene loci. Diabetes, Vol. 60, No. 1, (January 2011), pp. 127-137, ISSN 0021-1797

Ni, CY, Murphy, MP, Golde, TE \& Carpenter, G. (2001) $\gamma$-Secretase cleavage and nuclear localization of ErbB-4 receptor tyrosine kinase. Science, Vol. 294, No. 5549, (October 2001), pp. 2179-2181, ISSN 0036-8075

Offterdinger, M, Schöfer, C, Weipoltshammer, K, \& Grunt, TW. (2002) c-erbB-3: a nuclear protein in mammary epithelial cells. Journal of Cell Biology, Vol. 157, No. 6, (June 2002), pp. 929-939, ISSN 0021-9525

Paganoni, S, \& Ferreira, A. (2003) Expression and subcellular localization of Ror tyrosine kinase receptors are developmentally regulated in cultured hippocampal neurons. Journal of Neuroscience Research, Vol. 73. No. 4, (August 2003), pp. 429-440, ISSN 0360-4012 
Paganoni, S, \& Ferreira, A. (2005) Neurite extension in central neurons: a novel role for the receptor tyrosine kinases Ror1 and Ror2. Journal of Cell Science, Vol. 118, No. 2, (January 2005), pp. 433-446, ISSN 1477-9137

Pasquale, EB. Eph receptor signalling casts a wide net on cell behaviour. Nature Reviews Molecular Cell Biology, Vol. 6, No. 6, (June 2005), pp. 462-475, ISSN 1471-0072

Peng, Hu, Myers, J, Fang, X, Stachowiak, EK, Maher, PA, Martins, GG, Popescu, G, Berezney, R, \& Stachowiak, MK. (2002) Integrative nuclear FGFR1 signaling (INFS) pathway mediates activation of the tyrosine hydroxylase gene by angiotensin II, depolarization, and protein kinase C. Journal of Neurochemistry, Vol. 81, No. 3, (May 2002), pp. 506-524, ISSN 1471-4159

Pike, LJ. (2003) Lipid rafts: bringing order to chaos. Journal of Lipid Research, Vol. 44, No. 4, (April 2003), pp. 655-667, ISSN 0022-2275

Pitulescu, ME, \& Adams, RH. (2010) Eph/ephrin molecules--a hub for signaling and endocytosis. Genes and Development. Vol 24, No. 22, (November 2010), pp. 24802492, ISSN 0890-9369

Podlecki, DA, Smith, RM, Kao, M, Tsai, P, Huecksteadt, T, Brandenburg, D, Lasher, RS, Jarett, L, \& Olefsky, JM. (1987) Nuclear translocation of the insulin receptor. A possible mediator of insulin's long term effects. Journal of Biological Chemistry, Vol. 262, No. 7. (March 1987), pp. 3362-3368, ISSN 0021-9258

Poenie, M, Alderton, J, Tsien, RY, \& Steinhardt, RA. (1985) Changes of free calcium levels with stages of the cell division cycle. Nature, Vol. 315, No. 6015, (May 1985), pp. 147-149, ISSN 0028-0836

Psyrri, A, Yu, Z, Weinberger, PM, Sasaki, C, Haffty, B, Camp, R, Rimm, D \& Burtness, BA (2005) Quantitative determination of nuclear and cytoplasmic epidermal growth factor receptor expression in oropharyngeal squamous cell cancer by using automated quantitative analysis. Clinical Cancer Research, Vol. 11, No. 16, (August 2005), pp. 5856-5862, ISSN 1557-3265

Pusl, T, Wu, JJ, Zimmerman, TL, Zhang, L, Ehrlich, BE, Berchtold, MW, Hoek, JB, Karpen, SJ, Nathanson, MH, \& Bennett, AM. (2002) Epidermal growth factor-mediated activation of the ETS domain transcription factor Elk-1 requires nuclear calcium. Journal of Biological Chemistry, Vol. 277, No. 30, (July 2002), pp. 27517-27527, ISSN 0021-9258

Raper, SE, Burwen, SJ, Barker, ME, \& Jones, AL. (1987) Translocation of epidermal growth factor to the hepatocyte nucleus during rat liver regeneration. Gastroenterology, Vol. 92, No. 5, (May 1987), pp. 1243-1250, ISSN 0016-5085

Reilly, JF \& Maher PA. (2001) Importin $\beta$-mediated nuclear import of fibroblast growth factor receptor: role in cell proliferation. Journal of Cell Biology. Vol. 152, No. 6, (March 2001), pp. 1307-1312, ISSN 0021-9525

Riese, II DJ, \& Stern, DF. (1998) Specificity within the EGF/ErbB receptor family signaling network. BioEssays, Vol. 20, No. 1, (January 1998), pp. 41-48 ISSN 1521-1878

Riese, II DJ, van Raaij, TM, Plowman, GD, Andrews, GC, \& Stern, DF. (1995) Cellular response to neuregulins is governed by complex interactions of the ErbB receptor family. Molecular and Cellular Biology, Vol. 15, No. 10, (October 1995), pp. 5770-5776, ISSN 1098-5549 
Rodrigues, MA, Gomes, DA, Leite, MF, Grant, W, Zhang, L, Lam, W, Cheng, YC, Bennett, AM, \& Nathanson, MH. (2007) Nucleoplasmic calcium is required for cell proliferation. Journal of Biological Chemistry, Vol. 282, No. 23 (June 2007), pp. 1706117068, ISSN 0021-9258

Rodrigues, MA, Gomes, DA, Andrade, VA, Leite, MF, \& Nathanson MH. (2008) Insulin induces calcium signals in the nucleus of rat hepatocytes. Hepatology. Vol. 48, No. 5, (November 2008), pp. 1621-1631, ISSN 1527-3350

Salinas, S, Briançon-Marjollet, A, Bossis, G, Lopez, MA, Piechaczyk, M, Jariel-Encontre, I, Debant, A, \& Hipskind, RA. (2004) SUMOylation regulates nucleo-cytoplasmic shuttling of Elk-1. Journal of Cell Biology, Vol. 165, No. 6. (June 2004), pp. 767-773, ISSN 0021-9525

Schmahl, J, Kim, Y, Colvin, JS, Ornitz, DM, \& Capel B. (2004) Fgf9 induces proliferation and nuclear localization of FGFR2 in Sertoli precursors during male sex determination. Development 2004, 131(15):3627-3636. Cancer Research, Vol. 71, No. 12, (August 2004), pp. 4269-4279, ISSN 1538-7445

Sehat, B, Tofigh, A, Lin, Y, Trocmé, E, Liljedahl, U, Lagergren, J, \& Larsson, O. (2010) SUMOylation mediates the nuclear translocation and signaling of the IGF-1 receptor. Science Signaling, Vol. 3, No. 108, (February 2010), pp. ra10, ISSN 19450877

Sorkin, A, \& Waters, CM (1993) Endocytosis of growth factor receptors. Bioessays , Vol. 15, No. 6, (June 1993), pp. 375-382, ISSN 1521-1878

Stachowiak, MK, Moffett, J, Maher, PA, Tucholski, J, \& Stachowiak, EK. (1997) Growth factor regulation of cell growth and proliferation in the nervous system. A new intracrine nuclear mechanism. Molecular Neurobiology, Vol. 15, No. 3, (December 1997), pp. 1-27 ISSN 0893-7648

Stachowiak, MK, Fang, X, Myers, JM, Dunham, SM, Berezney, R, Maher, PA, \& Stachowiak, EK. (2003a) Integrative nuclear FGFR1 signaling (INFS) as a part of a universal "feed-forward-and-gate" signaling module that controls cell growth and differentiation. Journal of Cellular Biochemistry, Vol. 90, No. 4, (November 2003), pp. 662-691, ISSN 0730-2312

Stachowiak, EK, Fang, X, Myers, J, Dunham, S, Stachowiak, MK. (2003b) cAMP induced differentiation of human neuronal progenitor cells is mediated by nuclear fibroblast growth factor receptor-1 (FGFR1). Journal of Neurochemistry, Vol 84, No. 6, (March 2003), pp. 1296-1312, ISSN 1471-4159

Stephenson, SA, Slomka, S, Douglas, EL, Hewett, PJ, \& Hardingham, JE. (2001) Receptor protein tyrosine kinase EphB4 is up-regulated in colon cancer. BMC Molecular Biology, Vol. 2, (December 2001), pp. 15, ISSN 1471-2199

Stern, DF, Heffernan, PA, \& Weinberg, RA. (1986) p185, a product of the neu protooncogene, is a receptor-like protein associated with tyrosine kinase activity. Molecular and Cellular Biology, Vol. 6, No. 5, (May 1986), pp. 1729-1740, ISSN 1098-5549

Stewart, M, Turley, H, Cook, N, Pezzella, F, Pillai, G, Ogilvie, D, Cartlidge, S, Paterson, D, Copley, C, Kendrew, J, Barnes, C, Harris, AL, \& Gatter, KC. (2003) The angiogenic receptor KDR is widely distributed in human tissues and tumours and relocates 
intracellularly on phosphorylation. An immunohistochemical study. Histopathology. Vol. 43, No. 1, (July 2003), pp. 33-39, ISSN 1365-2559

Subbaramaiah, K, Norton, L, Gerald, W, and Dannenberg, AJ. (2002) Cyclooxygenase-2 is overexpressed in Her-2/neu-positive breast cancer: evidence for involvement of AP-1 and PEA3. Journal of Biological Chemistry, Vol. 277, No. 21, (May 2002), pp. 18649-18657, ISSN 1083-351X

Susarla, R, Gonzalez, AM, Watkinson, JC, \& Eggo, MC. (2011) Expression of receptors for VEGFS on normal human thyroid follicular cells and their role in follicle formation. Journal of Cellular Physiology, (July 2011), DOI 10.1002/jcp.22930, ISSN 1097-4652

Thaminy, S, Auerbach, D, Arnoldo, A, \& Stagljar, I. (2003) Identification of novel ErbB3interacting factors using the split-ubiquitin membrane yeast two-hybrid system. Genome Research, Vol. 13, No. 7, (July 2003), pp. 1744-1753, ISSN 1549-5469

Tidcombe, H, Jackson-Fisher, A, Mathers, K, Stern, DF, Gassmann, M, \& Golding, JP. (2003) Neural and mammary gland defects in ErbB4 knockout mice genetically rescued from embryonic lethality. Proceedings of the National Academy of Sciences of the USA, Vol. 100, No. 14, (July 2003), pp. 8281-8286, ISSN 1091-6490

Trudel, S, Ely, S, Farooqi, Y, Affer, M, Robbiani, DF, Chesi, M, Bergsagel, PL. (2004) Inhibition of fibroblast growth factor receptor 3 induces differentiation and apoptosis in t(4;14) myeloma. Blood, Vol. 103, No. 9, (May 2004) pp. 3521-8, ISSN 0006-4971

Tseng, HC, Lyu, PC, Lin, WC. (2010) Nuclear localization of orphan receptor protein kinase (Ror1) is mediated through the juxtamembrane domain. BMC Cell Biology, Vol. 11, (June 2010), pp. 48, ISSN 1471-2121

Turini, ME, \& DuBois, RN. (2002) Cyclooxygenase-2: a therapeutic target. Annual Review of Medicine, Vol. 53, (2002), pp. 35-57, ISSN 0066-4219

Vadlamudi, R, Mandal, M, Adam, L, Steinbach, G, Mendelsohn, J, \& Kumar, R. (1999) Regulation of cyclooxygenase-2 pathway by HER2 receptor. Oncogene, Vol. 18, No. 2, (January 1999), pp. 305-314, ISSN 0950-9232

Wang, MH, Padhye, SS, Guin, S, Ma, Q, \& Zhou, YQ. (2010) Potential therapeutics specific to c-MET/RON receptor tyrosine kinases for molecular targeting in cancer therapy. Acta Pharmacologica Sinica, Vol. 31, No. 9, (September 2010), pp. 1181-1188, ISSN 1745-7254

Wang, SC, Nakajima, Y, Yu, YL, Xia, W, Chen, CT, Yang, CC, McIntush, EW, Li, LY, Hawke, DH, Kobayashi, R, \& Hung, MC. (2006) Tyrosine phosphorylation controls PCNA function through protein stability. Nature Cell Biology, Vol. 8, No. 12, (December 2006), pp. 1359-1368, ISSN 1465-7392

Wang, Y, Pennock, SD, Chen, X, Kazlauskas, A, \& Wang, Z. (2004a) Platelet-derived growth factor receptor-mediated signal transduction from endosomes. Journal of Biological Chemistry, Vol. 279, No.9, (February 2004), pp. 8038 - 8046, ISSN 0021-9258

Wang, SC, Lien, HC, Xia, W, Chen, IF, Lo, HW, Wang, Z, Ali-Seyed, M, Lee, DF, Bartholomeusz, G, Ou-Yang, F, Giri, DK, \& Hung MC (2004b) Binding at and transactivation of the COX-2 promoter by nuclear tyrosine kinase receptor ErbB-2. Cancer Cell. Vol. 6, No. 3, (September 2004), pp. 251-261, ISSN 1535-6108 
Wang, SC, \& Hung, MC. (2009) Nuclear translocation of the EGFR family membrane tyrosine kinase receptors. Clinical Cancer Research, Vol. 15, No. 21, (November 2009), pp. 6484-6489, ISSN 1078-0432

Wanner, G, Mayer, C, Kehlbach, R, Rodemann, HP, \& Dittmann, K. (2008) Activation of protein kinase $\mathrm{C}$ epsilon stimulates DNA-repair via epidermal growth factor receptor nuclear accumulation. Radiotherapy and Oncology, Vol 86, No. 3, (March 2008), pp. 383-390, ISSN 0167-8140

Wells, A, \& Marti, U. (2002) Signalling shortcuts: cell-surface receptors in the nucleus? Nature Reviews Molecular Cell Biology, Vol. 3, No. 9, (September 2002), pp. 697-702, ISSN 1471-0072

Wesche, J, Haglund, K, \& Haugsten, EM. (2011) Fibroblast growth factors and their receptors in cancer. Biochemical Journal, Vol. 437, No. 2, (July 2011), pp. 199-213, ISSN 0264-6021

Wilkinson, KA \& Henley, JM. (2010) Mechanisms, regulation and consequences of protein SUMOylation. Biochemistry Journal, Vol. 428, No. 2, (May 2010), pp. 133-145, ISSN 0264-6021

Williams, CC, Allison, JG, Vidal, GA, Burow, ME, Beckman, BS, Marrero, L, Jones, FE. (2004) The ERBB4/HER4 receptor tyrosine kinase regulates gene expression by functioning as a STAT5A nuclear chaperone. Journal Cell Biology, Vol. 167, No. 3, (November 2004), pp. 469-478, ISSN 0021-9258

Xia, W, Wei, Y, Du, Y, Liu, J, Chang, B, Yu, YL, et al.,. Nuclear expression of epidermal growth factor receptor is a novel prognostic value in patients with ovarian cancer. Molecular Carcinogenesis, Vol. 48, No. 7, (July 2009), pp. 610-617, ISSN 1098-2744

Xu, J, He, Y, Qiang, B, Yuan, J, Peng, X, \& Pan, XM. (2008) A novel method for high accuracy sumoylation site prediction from protein sequences. BMC Bioinformatics, Vol. 9, (January 2008), pp. 8, ISSN 1471-2105

Xu, Y, Shao, Y, Zhou, J, Voorhees, JJ, \& Fisher, GJ. (2009) Ultraviolet irradiation-induces epidermal growth factor receptor (EGFR) nuclear translocation in human keratinocytes. Journal of Cell Biochemistry, Vol. 107, No. 5, (August 2009), pp. 873880, ISSN 0021-9258

Yao, Y, Wang, G, Li, Z, Yan, B, Guo, Y, Jiang, X, \& Xi, J. (2010) Mitochondrially localized EGFR is independent of its endocytosis and associates with cell viability. Acta Biochimica et Biophysica Sinica (Singapore), Vol. 42, No. 11, (November 2010), pp. 763770, ISSN 1672-9145

Yoo, JY, \& Hamburger, AW. (1999) Interaction of the p23/p198 protein with ErbB-3. Gene, Vol. 229, No. 1-2, (March 1999), pp. 215-221, ISSN 0378-1119

Youngren JF. (2007) Regulation of insulin receptor function. Cellular and Molecular Life Sciences, Vol. 64, No. 7-8, (April 2007), pp. 873 - 891, ISSN 1420-682X

Zaczek, A, Brandt, B, \& Bielawski, KP. (2005) The diverse signaling network of EGFR, HER2, HER3 and HER4 tyrosine kinase receptors and the consequences for therapeutic approaches. Histology and Histopathology, Vol. 20, No. 3, (July 2005), pp. 1005-1015, ISSN 0213-3911

Zhang, Z, Yang, Y, Gong, A, Wang, C, Liang, Y, \& Chen Y. (2005) Localization of NGF and TrkA at mitotic apparatus in human glioma cell line U251. Biochemical and 
Biophysical Research Communications, Vol. 337, No. 1, (November 2005), pp. 68-74, ISSN 0006-291X

Zhong, J, Kim, H, Lyu, J, Yoshikawa, K, Nakafuku, M \& Lu1, W (2011) The Wnt receptor Ryk controls specification of GABAergic neurons versus oligodendrocytes during telencephalon development. Development, Vol. 138, No. 3, (February 2011), pp. 409419, ISSN 1011-6370 


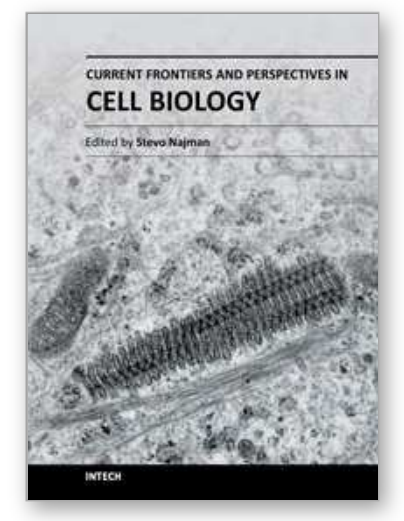

\section{Current Frontiers and Perspectives in Cell Biology \\ Edited by Prof. Stevo Najman}

ISBN 978-953-51-0544-2

Hard cover, 556 pages

Publisher InTech

Published online 25, April, 2012

Published in print edition April, 2012

\section{How to reference}

In order to correctly reference this scholarly work, feel free to copy and paste the following:

Sally-Anne Stephenson, Inga Mertens-Walker and Adrian Herington (2012). Signaling of Receptor Tyrosine Kinases in the Nucleus, Current Frontiers and Perspectives in Cell Biology, Prof. Stevo Najman (Ed.), ISBN: 978-953-51-0544-2, InTech, Available from: http://www.intechopen.com/books/current-frontiers-andperspectives-in-cell-biology/signaling-of-receptor-tyrosine-kinases-in-the-nucleus

\section{INTECH}

open science | open minds

\section{InTech Europe}

University Campus STeP Ri

Slavka Krautzeka 83/A

51000 Rijeka, Croatia

Phone: +385 (51) 770447

Fax: +385 (51) 686166

www.intechopen.com

\section{InTech China}

Unit 405, Office Block, Hotel Equatorial Shanghai

No.65, Yan An Road (West), Shanghai, 200040, China

中国上海市延安西路65号上海国际贵都大饭店办公楼405单元

Phone: +86-21-62489820

Fax: $+86-21-62489821$ 
(C) 2012 The Author(s). Licensee IntechOpen. This is an open access article distributed under the terms of the Creative Commons Attribution 3.0 License, which permits unrestricted use, distribution, and reproduction in any medium, provided the original work is properly cited. 